\title{
Design, Strategy, and Collaboration: A System an Alternative for Reusing Waste from the Bespoke Furniture Sector
}

\author{
${ }^{1}$ Viviane G. A. Nunes, ${ }^{2}$ Júlia S. Abrão \\ 1,2 Faculty of Architecture and Urbanism and Design, Federal University of Uberlândia, \\ Uberlândia, Brazil
}

\begin{abstract}
This work describes the proposal of a collaborative inter-organizational network involving different actors operating as a group. The aim was to reuse the waste generated by the custom-made furniture sector, which is very relevant in Brazil. The presented scenario is the city of Uberlandia/MG/Brazil, a medium-sized city, which produces about $30.000 \mathrm{~m} 3 /$ year of furniture production waste. The proposed collaborative network involves a furniture microenterprise, a primary public school, and a federal University, with the coordination of the last one, linked by design concepts. The theoretical references are based on the building of interorganizational collaborative networks, Strategic Design, and Design for Social Innovation and Sustainability. The research methodology was based on an action-research process, and the methods were divided into a literature review, case studies, data collection and the development of new and small products. The obtained results are related to the value perception of collaboration among actors and the importance of continuous social innovation practices but also of technological ones. This confirms the feasibility of absorption of new practices into the daily operations both in the microenterprise and the public school as well within the university, as a way of increasing the positive impacts coming from these initiatives and a chance of scaling up the project.
\end{abstract}

Keywords: Inter-organizational collaborative networks; Bespoke furniture sector; Boundary objects; Strategic design for sustainability

\section{Introduction}

Uberlândia/MG/Brasil is known as a central city of the Triângulo Mineiro region, with almost 700,000 inhabitants (G1 Triângulo Mineiro, 2017). In the recent years, although the municipality has not been fully consolidated as a Local Productive Arrangement (APL) in the furniture production field, the local furniture industry, especially the micro-producers portion, has been growing more and more, contributing to the development of the microregion. According to SENAI, FIEMG, SEBRAE, \& SINDMOB (2006) and Oliveira, Alvarenga, Paes, Feitosa, \& Silva (2012), the Triângulo Mineiro and Alto Paranaíba region had, in 2012, about 800 micro and small productive enterprises (MSEs), which produced custom-made furniture almost exclusively. Recent researchers have pointed to a less number of existing companies, around 500 among formally registered micro and small enterprises (Abrão, 2017).

On the other hand, in spite of the contribution of these companies to the economic dynamics of the region, tons of waste produced by them have been deposited in landfills and, even worse, in many cases, they are disposed of in inappropriate places such as wastelands. Such actions have a direct effect not only on the environment but also on the group of professionals in charge of such activities, who are in contact with such environments, and the general population. It is worth noting that the problem is not linked only to the incorrect disposal of waste, but to the integrated management of the company, i.e., how it deals with 
production issues, environmental issues, its relationship with the corporate social responsibility and competitiveness principles.

Currently, the volume of furniture waste dumped in landfills and wastelands in the Uberlândia/ MG region is very high. According to estimates made in 2012 (Nunes, 2012) and the recent data collected in a research that has been developed since then, it has been found that companies discard an average of $420 \mathrm{~kg}$ of MDF a week which amounts to about 340 tons a month deposited in the landfill, considering the 800 SMEs (Oliveira et al., 2012)1. In terms of volume, from the estimated disposal and the data collected since, an increase of about $50 \%$ was noticed, from around 22,000m3 in 2012 (Nunes, 2012) to around 33,000m3 in 2017 (Abrão, 2017). Another environmental concern that is also related to improper disposal is the burning of MDF outdoors. According to reports collected during field research, burning has also occurred in grills, ovens and other places where food products are manipulated. Burning both outdoors and in non-energy furnaces, releases polluting gases into the environment both because the MDF contains resins and the parts have received some type of paint or are coated in some plastic (Wildner, 2015). Although the Administrative Measure No. 009/2012, of February 08, 2012, article no. 4 (FEPAM, 2012), was created to reduce the emission of toxic gases in the atmosphere from the burning of MDF and MDP by the industry furniture, many actions of this nature have still occurred in several parts of the country.

Such data only make it evident that despite the many types of research that have been developed in the city in the last eight years on this subject (see Nunes, 2013; Zurlo \& Nunes, 2016), up until now, few have sensitized the sector and the local government.

Based on some authors (Todeva \& Knoke, 2005; Tsai, 2009), for Zurlo and Nunes (2016, p.27),

the engagement in partnerships within inter-organizational collaboration networks depends on the purposes of the actual partnerships, on the features of the organizations and multiple environmental factors. In different levels, each factor comprises specific is sues to address change and performance improvement.

In such a way, solutions to identify core problems and the common goals must include the external dimensions of such a system. As viable solutions to the lack of resources and capabilities are not often available within a private company (Das \& Teng, 2000), inter-organizational collaborative networks constitute an appropriate mechanism to operate to reach innovative and more sustainable solutions (Zurlo \& Nunes, 2016). Some authors also argue that Design can take on a central role, not only by contributing with qualified knowledge, but by motivating the promotion of scenarios that allow better solutions to be sought in projects, processes, services and even strategies (Zurlo, 1999; Mozota, 2003; Best, 2006; Rossi Filho, Meroni, Monti, \& Galisai, 2009). Design can also act on the promotion of budding initiatives that foster the creation of contextualized design policies integrated with the idea of these inter-organizational collaborative networks as a mechanism for the sustainable development of a region (Zurlo \& Nunes, 2016).

As explained, the local scenario presents a high volume of waste generated by the custom-made furniture sector, which causes much environmental impact. So, it is necessary to investigate the possible contributions of Design as a tool for change in the behavior of businesses. To do this, we came up with the critical question for this research: how to design a Collaborative Network that works as an alternative strategy for reusing this waste?

1. The 800 companies were kept (Oliveira et al., 2012) to ensure the comparison between the amounts raised in 2012 and 2017. If the updated number is considered, the volume of waste should be proportionally reduced. 
Design, Strategy, and Collaboration: A System an Alternative for Reusing Waste from the Bespoke Furniture Sector

Viviane G. A. Nunes, Júlia S. Abrão

The goal of this work was, therefore, to design a collaborative interorganizational network with the participation of several actors that could work together to reuse the waste generated by the custom-made furniture sector in the city of Uberlândia/MG. As mentioned above, individual participation in the system would also require every actor to play a specific role in a systemic and coordinated way, to ensure the effectiveness of the operation and the success of this experience.

The construction of the inter-organizational network had three types of organizations, namely: the university, represented by the design school, a furniture company micro-enterprise and a municipal school for children's education. Thus, both the researcher and the participants worked together to solve a common problem: the large volume of waste generated by the furniture sector in Uberlândia. In order to face these issues from a design standpoint, the theoretical references were based on inter-organizational collaborative networks building (Zurlo \& Nunes, 2016), Strategic Design (Mozota, 2011, Zurlo, 2012), Design for Social Innovation and Sustainability (Manzini, Collina, \& Evans, 2004; Manzini, 2008; Manzini \& Vezzoli, 2008; Cavalcante, Preto, Pereira, \& Figueiredo, 2012), Circular Economy (WEF, 2014; EEA, 2017) and Socioenvironmental Responsibility (Kazazian, 2005; Tachizawa, 2002; Santos, Vezzoli, Cortesi, 2008) within the furniture sector.

The study was outlined through the research methodology known as action research, defined by Thiollent (1985) as a type of empirical research carried out along with an action that involves the solution of a collective problem, in which researchers and participants who are part of the situation or problem are engaged in a cooperative and participatory way. The research process was divided into (i) review of literature involving documental and bibliographic researches; (ii) case studies to identify and analyze successful cases; (iii) data collection in loco (interviews and questionnaires); and (iv) the development of new products from small pieces of MDF and other panels. There were also adopted some design tools to generate and analyze the developed solutions.

\section{The Proposed Intervention Based on the Adopted Theoretical Framework}

\section{Concept of Collaborative Inter-organizational Networks}

According to Cipolla (2004 cited in Manzini, 2008, p.71), when collaborative networks are discussed, it is assumed that the main point links all networks. It can also be observed that both the commitment and the investment of actors in this interconnected system will grow gradually, as the coalition increase (figure 1).

However, much the groups differ from one another, with various actors and objectives in each, somehow collaborative networks are interconnected because all of them contain a group of people working together in the co-creation of concepts, which most of the time are recognized and shared due to an internal goal of the network that's common to the group.

For Loss (2007), the collaborative performance with strategic partnerships through Collaborative Networks was one of the solutions found by today's companies to continue expanding in a capitalist and increasingly competitive market.

The Inter-organizational Collaborative Network (ICoN) model proposed by Zurlo and Nunes (2016) shows that, despite the individual actions, relationships have mostly interdependent operations that enable the functioning of the system as a whole. Based in several authors, Zurlo and Nunes (2016) state that the purpose of such connecting ICoN can be associated with many positive reasons, for many typologies of actors which are involved in it, such as, (1) university, 
Design, Strategy, and Collaboration: A System an Alternative for Reusing Waste from the Bespoke Furniture Sector

Viviane G. A. Nunes, Júlia S. Abrão

research and funding institutions and government, (2) business organizations and (3) community associations and/or NGOs.

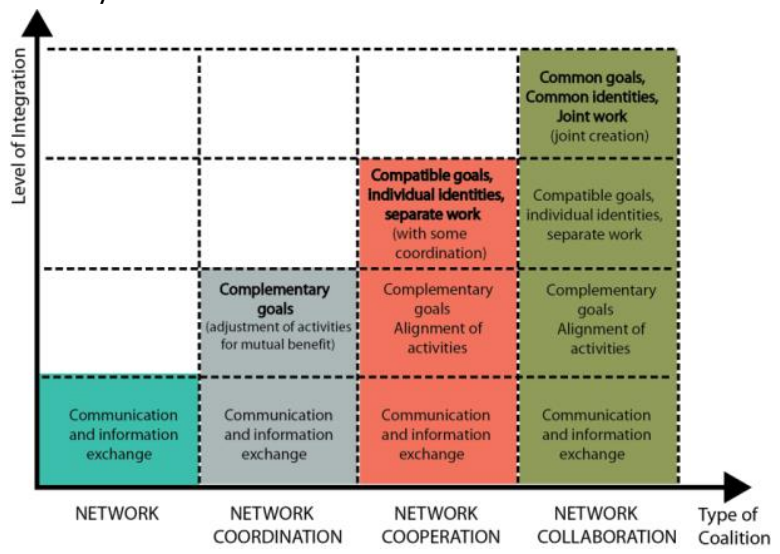

Figure 1: Collective activities. Source: Abrão (2017 based on Camarinha-Matos and Afsarmansh (2006 cited in Loss, 2007)

As for the reasons, we can list the following: for actors type 1, the interest in developing new knowledge, the need to communicate among actors that usually do not collaborate, and the reduction of environmental impacts that come with unsustainable practices and production processes. For actors type 2, the increase of skills, productive capacities and co-production value, the earning of future business opportunities and the compliance with specific requirements of environmental and a sustainability changes and; for actors type 3 , the improvement of social conditions (Zurlo \& Nunes, 2016). Also, the furniture designed within the project was considered a boundary object (Nunes, 2013; Zurlo \& Nunes, 2016), i.e., a connecting element among actors that favors understanding and trust.

\section{Sustainable Design}

Concerns with the environment must be associated with a culture that guarantees the preservation of the planet and supports collective commitment. According to several authors (Chelala, 2008; Manzini \&Vezzoli, 2008; Clark, Kosoris, Hong, \& Crul, 2009; Cavalcante et al., 2012), sustainable development acts on the premise of providing solutions for the reuse of natural resources, encompassing social, environmental and economic dimensions, among others. The major contemporary challenge is the transition from the design process of producing and consuming, so that the "culture of quantity " may evolve into the "culture of quality" and these qualities are accepted by society and supported by the environment (Manzini, 1993 cited in Nunes, 2008).

According to Nunes (2008), the term "culture of quality" is related to environmental protection issues, ways to design more efficient usage of resources, through programmed consumption and the reduction of waste. Within the "culture of quality", the use of new materials, in addition to meeting the needs of its use should be aimed at minimizing the disruption of the system. In keeping with Manzini (1993), Nunes (2008) presents three scenarios to make this possible: 1) the minimal material scenario, 2) the eternal material scenario, and 3) the average material scenario (figure 2).
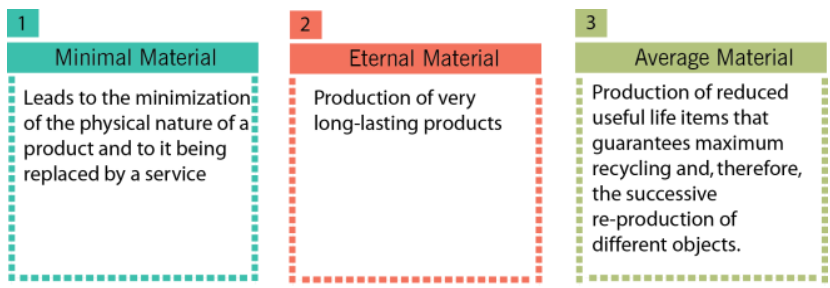
Design, Strategy, and Collaboration: A System an Alternative for Reusing Waste from the Bespoke Furniture Sector

Viviane G. A. Nunes, Júlia S. Abrão

Figure 2: Culture scenarios of quality. Source: Abrão (2017a) based on Nunes (2008)

The search for eco-friendly and sustainable products project arises; therefore, from the perception that natural resources are limited. Thus, companies that intend to continue in the market must implement a sustainable and ecological design in their production and management system (Manzini \& Vezzoli, 2008).

While discussing the Design for Susta inability, Cavalcante et al. (2012) mention some concepts and principles from other knowledge fields, trying to inter-relate them in order to create a broad overview. The authors point to interdisciplinary concepts that encompass the environmental, economic and social dimensions and the interdependency of products and services. First, similarly to some other already mentioned authors, they argue that Sustainable Development is related to three dimensions:

- Environmental dimension as a path to minimize impacts, and related to environmental education, environmental management, clean production mechanisms, and sustainable consumption;

- The social dimension, related to poverty eradication, decent work conditions, the overcoming of social inequalities, the inclusion of marginalized groups and social diversity;

- Economic dimension, related to natural capitalism, fair trade, and solidarity economy.

These dimensions are strictly related to themselves, aiming at satisfying the present and future needs. To achieve this, the authors connect a series of concepts that should be activated and work in interdependent relations as:

- Industrial ecology, related to dematerialization and industrial metabolism;

- Green economy, related to poverty reduction, sustainable cities, and su stained inclusive and equal growth;

- Natural capitalism, reference the availability of natural capital, democratic systems of production and distribution, overcoming inequalities.

According to Cavalcante et al. (2012), Green economy and Natural capitalism are both related to green markets, innovation, and social wellbeing. Also,

- The interdependence of products and services stimulates precaution and responsibility and is related to biocompatibility and eco-efficiency. These are, therefore, related to eco-design, eco-conception and the life cycle design of the product system.

As we can see, the design is part of the context as the social-environmental demand in which the need for sustainable products development and an alternative development economy emerges.

This approach is in tune with the circular economy model that requires the reformulation of economic practices and is based on natural systems. Indeed, the transition towards this sustainable economy requires core changes to consumption-production-disposal systems, which means going much beyond resource efficiency and waste recycling (EEA, 2017). The circular economy demands a closed life cycle of products, to reduce raw material, energy, and water consumption. In this scenario, companies become, simultaneously, consumers and suppliers of materials that are reincorporated into the production cycle (WEF, 2014) (figure 3).

It is worth mentioning that current actions, policies, and tools are more focused on waste and material solutions. Strategies related to reuse, repair, redistribution, remanufacture and 
Design, Strategy, and Collaboration: A System an Alternative for Reusing Waste from the Bespoke Furniture Sector

Viviane G. A. Nunes, Júlia S. Abrão

refurbishment are less mature and have received less attention than waste-related issues. In any case, such methods play an important role when encouraging innovations in designing more environmentally friendly products.

To respond to societal needs in the contemporary world, the achievement of a circular economy depends on smarter designs, with long life spam and new roles for them within the system, but in contextualized solutions (EEA, 2017). Moreover, it also requires, especially from local contexts, a deep awareness about the connection between products, the existing business models and societal infrastructure as well as governance to determine technologies and life cycles.
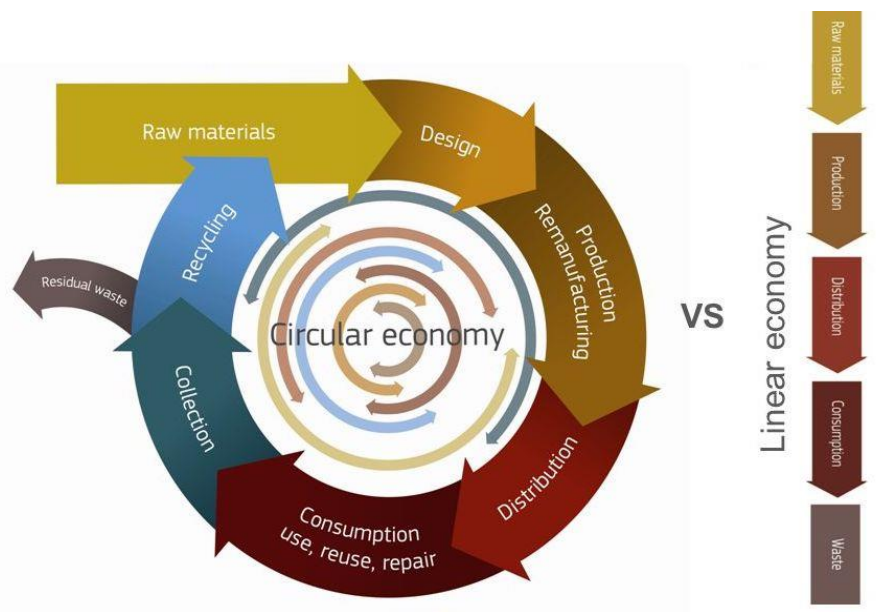

Figure 3: Concept of Circular Economy. Source: Bacigalupi, 2015

\section{Strategic Design and Social and Environmental Responsibility}

The strategic design unites different areas within an organization. It is a project activity whose objective is to understand the reality and to develop products, services, and experiences based on the incorporation of diverse knowledge (Meroni, 2008 cited in Scaletsky, Costa \& Bittencourt, 2016). According to the authors, Strategic Design "makes space for the integration of diverse specialized knowledge, [which] provides a complete view of all aspects" (Scaletsky et al., 2016). Zurlo (2012) argues that strategic design is linked to the ability of design to see, predict and "make see" (i.e., show).

The strategic vision within the company seeks to assist business management in issues regarding administration, infrastructure, human resources, among others, to make the company more competitive. This point of view is also related to environmental issues, contributing to the better performance of a company in comparison with its competitors, and at the same time satisfying the needs of the market. In th is context, the role of design is to predict these scenarios to be able to elaborate sustainable strategies, becoming the critical piece in about business competitiveness (Teixeira, 2005, p.27).

Thus, the design provides support to companies in different forms, especially to micro and small businesses (Bruce, Cooper, and Vazquez, 1999). This means that, besides the management of the processes and product creation, the design also focuses on improving customer services and experiences. Likewise, the design contributes to increasing company efficiency as well as defining waste reduction strategies (Mozota, 2003; Best, 2006) by working in different levels, i.e., in the operational, tactical and/or strategic level. In addition to the strategic aspects of design mentioned above, we highlight the issue of corporate responsibility, directly linked to human behavior, as theorized by Hans Jonas, in 1979, on the principles of individual 
Design, Strategy, and Collaboration: A System an Alternative for Reusing Waste from the Bespoke Furniture Sector

Viviane G. A. Nunes, Júlia S. Abrão

responsibility, based on the question of an "irresponsible act." For the author, regardless of the fact $d$ to blame for an incorrect action to be an individual or a group of persons, there must be one of the obligations responsible for the consequences of the involved the acts committed. This principle encourages the culprit to take responsibility for the implications, without having to be bound by any authority (Kazazian, 2005 p.32).

In this context, considering that progressive changes in corporate behavior to sustainable businesses, can result in more significant economic effect, companies that adopt the strategic guidelines related to issues such environmental and ecological can also reach competitive advantages (Tachizawa, 2002), in addition to contributing substantially to the increase in socioenvironmental quality resulting from its market performance.

\section{Proposed Inter-Organizational Network Configurations: Analyses and Adjustments}

As it has been mentioned, this work is aimed at the creation of an interorganizational collaborative network, that is a system composed of organizations of different natures, to reuse the waste generated during the production of custom-made furniture. After the review of the literature, the context diagnostic and the identification of potential partners for the network came to the system definition stage (figure 4).

The first configuration involved five actors: the university, a furniture micro-enterprise, the city council, daycare and an NGO, each of which is responsible for fulfilling their role, as follows:

- University: key role in coordinating the collaborative network, designing the projects, and also monitoring the manufacture of furniture as well as its installation in daycare centers. It was also expected to be responsible for the analysis of use and suitability, if necessary.

- Furniture micro-enterprise (wood shop): responsible for the donation of useful waste to the $\mathrm{NGO}$, in a controlled way - the donor should separate, store and deliver the leftovers to the final recipient.

- NGO: responsible for 1) manufacturing the furniture, based on design blueprints developed and donated by a UFU design course student; 2 ) seek to get closer to the PMU to establish a partnership for selling the furniture, in a pilot experiment.

- Uberlândia City Council (PMU): the consumer (through acquisition) or free user of the furniture, taking it to the municipal daycares and allowing use and suitability analyses to be carried out in future proposals for scaling up the experience.

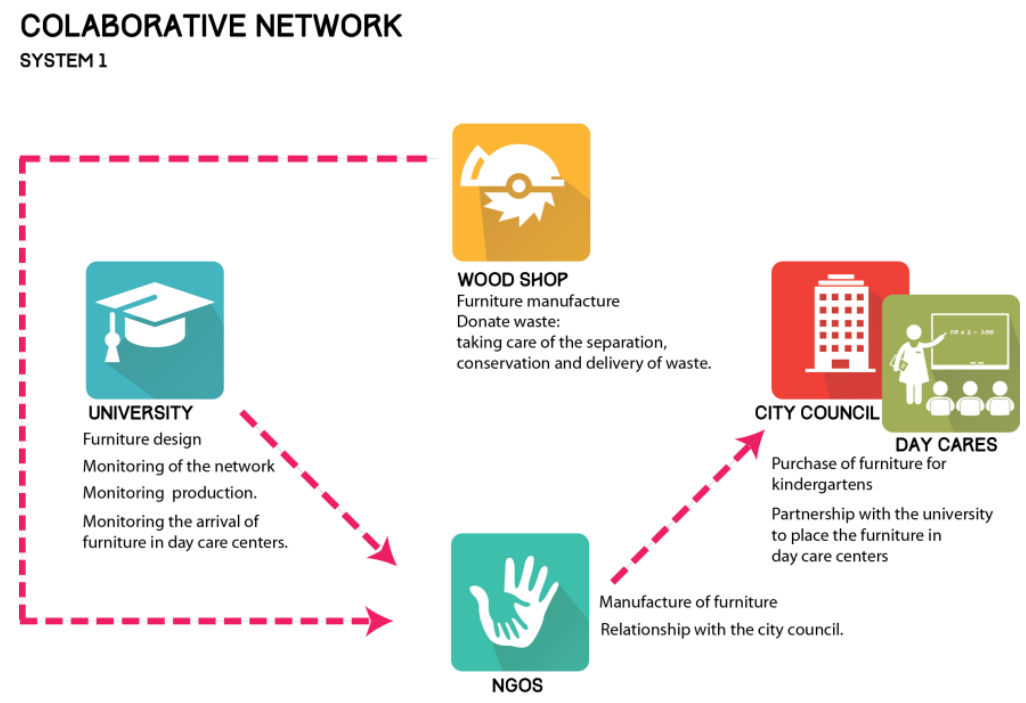


Design, Strategy, and Collaboration: A System an Alternative for Reusing Waste from the Bespoke Furniture Sector

Viviane G. A. Nunes, Júlia S. Abrão

Figure 4: Collaborative Network System 1. Source: Abrão (2017a)

For the definition of the participation of the actors in the proposed network system, the questionnaire method was used for each one of the predicted actors (an NGO and a furniture microenterprise). The semi-structured questionnaire presented a summary of the project and the collaborative network and the roles of the participating actors. It had questions aimed at identifying the characteristics of the participant (defined as an actor or organization) and also questions related to their interest in participating in the system.

The selected NGO has a small wood shop and works with waste from the furniture sector, producing small objects. Regarding their participation in the proposed network, the NGO representative showed much interest but made it clear that one of the obstacles for their collaboration would be the lack of workforce for the manufacturing of furniture. According to him, the students of the university should offer labor; otherwise, it would be possible only to receive the waste and pass it forward. About furniture micro-enterprises, two companies were initially selected from the volume (high) of weekly waste disposal. At company one, it was not possible to use the questionnaire due to the unavailability of the owner's schedule. At company 2 , the questionnaire was applied, but the owner had no interest in participating in the project, stating that MDF is fragile and inadequate for the production of tables and chairs. After getting in contact with all the actors mentioned in System 1, it was observed the difficulty of involving the NGO actor, and so a new system was proposed, excluding the NGO from the network altogether. Also considering that it would not be possible to form the collaborative network without the participation of a furniture micro-enterprise, Company 1 was contacted aga in. Thus, the final configuration of the proposed collaborative inter-organizational network was defined as follows: University, wood shop (a furniture microenterprise initially represented by company 1 ), product designer, Daycare and community (figure 5 ).

The UFU (understood here as their Design School) took on the role of central facilitator to the entire interconnected system. Among its responsibilities are: (i) coordinating the collaborative network, (ii) monitoring the development of furniture projects to meet the needs of the Daycare, (iii) selecting and delivering (experimentally) the wood scraps ${ }^{2}$ For the manufacturer, (iv) monitoring the manufacture of furniture and its installation in daycares ( $v$ ) analyze the use and propose enhancements, if needed. The wood shops could be involved in two ways: (i) passive indirect collaborator, that is, donating the waste to the UFU, also being responsible for separating, storing and delivering the leftovers to the university; (ii) active direct collaborator, in charge of manufacturing the furniture using the waste of their own company or other companies, in addition to separating and conserving that material, and delivering the furniture to the Daycare Center.

\footnotetext{
2. The scraps refer to color-coated wood scraps for the end users (children); in addition to this, given the lack of available color-coated scraps, it might be necessary to get it from various companies.
} 


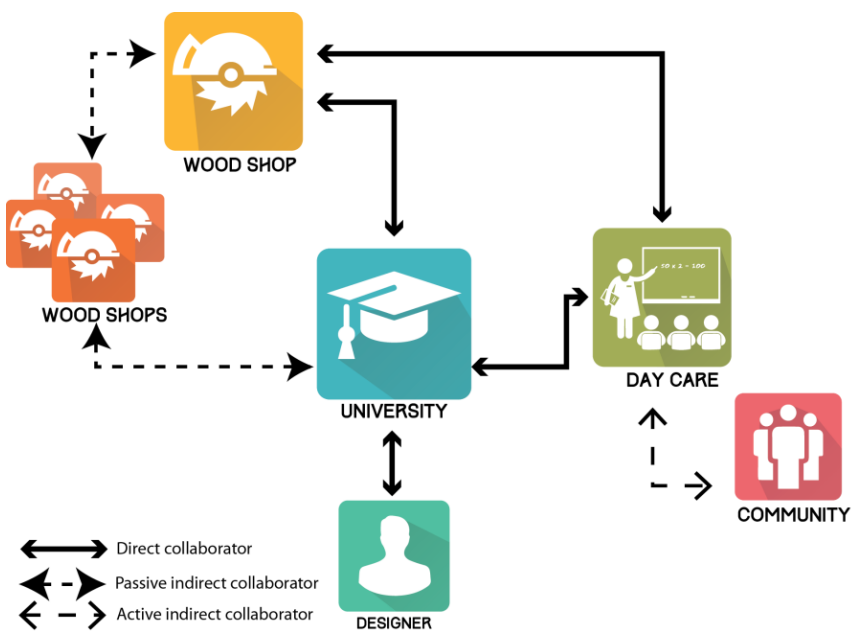

Figure 5: Final system proposed. Source: Abrão (2017a)

The Designer would be directly connected to the UFU, performing tasks that are the institution's responsibility and also in charge of drafting the projects for furniture from the reuse of waste to the collaborative network. The designer would also take on the role of the network's primary facilitator, along with the university.

The Daycare would be the partner user organization, responsible for purchasing the furniture, at cost, produced by the partner wood shop. Their collaboration would also involve the permission to monitor the use of the furniture, for the evaluation of both its suitability and its technical quality. Considering that the institution receives resources from the PMU to acquire the necessary equipment for the operation, its participation would be made realizable by the offer of furniture at a more affordable price, possible through the collaboration of the partner company.

The role of the Community (as an active indirect collaborator) would be the financial support for the acquisition of the equipment produced, from the collection of resources through campaigns. As reported, the funds made available by the PMU would not be sufficient for the purchase of all the necessary items for the operation of the institution.

The difference between passive or active collaborator is the degree of performance of the actors in the system. In the case of the company, it could act passively (only by donating waste) or active, also working in the production; in both cases, the company takes on the responsibility of working internally to maintain the organization of waste, ensuring its quality and feasibility of reuse. The community was considered an active contributor because the acquisition of the furniture would depend on its direct action on the allocation of resources.

\section{Furniture Prototypes as Boundary Objects to Facilitate Enable Engagement and Synergy}

This study adopts the Boundary Objects concept as a promoter of communication at the boundaries. These are components that facilitate a common language to build new knowledge among partakers in collaborative processes (Zurlo \& Nunes, 2016). Carlile (2002) and Zurlo and Nunes (2016) also suggest the adoption of prototypes and other boundary objects to transform knowledge collectively. Thus, this work also uses the prototypes as a common language aimed at creating an interface through design among partners to favor commitment and synergy for their collaboration in networks. 
Design, Strategy, and Collaboration: A System an Alternative for Reusing Waste from the Bespoke Furniture Sector

Viviane G. A. Nunes, Júlia S. Abrão

The furniture projects were developed from the references of user-centered design, aiming at the thorough fulfillment of the needs of the daycare partner. In addition to this the following were also evaluated: (i) space viability, from on-site visits and subsequent flow analysis and compatibility of use; (ii) the technical-executive viability of the objects; (iii) the economic feasibility of production for all partners involved, in line with the primary objective of creating the collaborative network.

Here it is worth highlighting that the technology available to produce furniture pieces was manual, and was determinant to define the technical execution of objects, sometimes limiting very innovative solutions. Moreover, since the objects were defined to respond to need and user, most composition parts should cater to the initial briefing. The results also need to take into consideration the daily conditions of maintenance and durability of objects, during their future use. All these aspects were essential in defining the guidelines for designing. After specifying the objects to be designed, the guiding principles for the creation of the pieces were defined: 1) simple design, similar to the furniture already used by Uberlandia City Council (considering that the nursery is municipal and managed by the City Hall): 2) reuse (MDF scraps), which are difficult to reuse within the company, in the form of custom-made furniture projects; and 3) maintenance of the main primary features of the furniture piece, such as: patchworking, intemal joints system and the "+" base.

Considering the crucial role of the prototype for the consolidation of the complex system, in making agreements easier, acting as a universal language element, i.e., a boundary object, the entire process of prototyping was supervised by the researchers, to propose adjustments if necessary. For a better perception of the design, production and use process, the following objects will be presented and prototyped to the partner company, the business actor.

\section{Table and Bank Re-Tales}

The Re-Tales table and stool follow the same standards. Both are intended to reuse mainly small parts. For the table, a mesh of residues was created for its top; due to its little surface, the stool used a whole piece. The feet two straight boards crossed that form a' + ' figure that makes the piece sturdier. Locked systems below the top and between the legs increase support and balance. Since it is child-friendly furniture, the existing coating on the remains of the MDF was kept to make the furniture playful and colorful (figure 6).
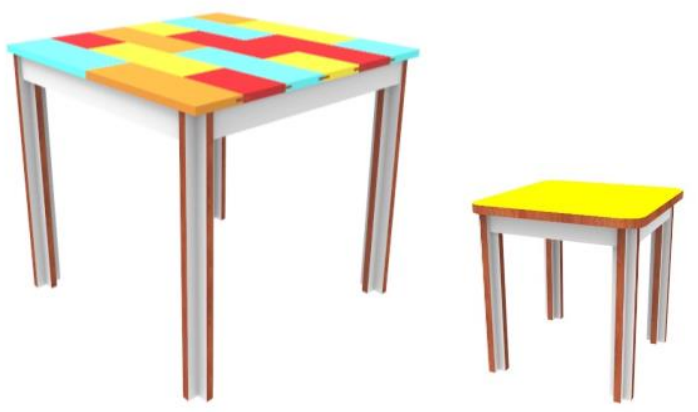

Figure 6: Table and bench made out of scraps. Source: Abrão (2017a)

\section{Re-Tales Cabinet and Shelf}

The two pieces of furniture were designed to optimize the use of the material (although they are already reused) in an attempt to use the most appropriate pieces, generating little residue from the second processing stage. The project considered the accommodation of the objects, taking into account users - children - and their access clearance (figures 7 and 8 ). 


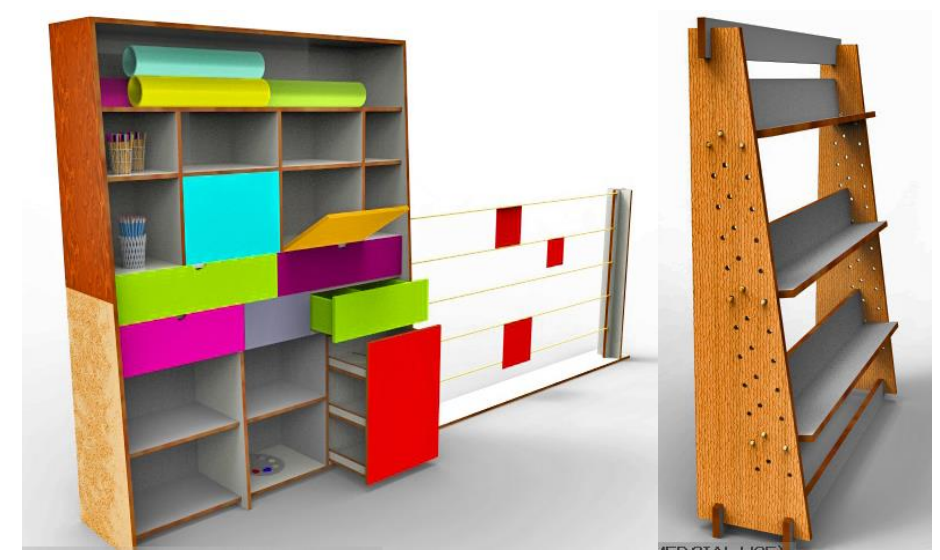

Figures 7 and 8: R-Tales Cabinet and Shelf. Source: Abrão (2017a)

After the design stage, producers prepared a manufacturing budget to be presented to the Daycare center: the NGO and the company 1 participated in the quote. The budget was expected to be fair, considering the principles adopted for the consolidation of the collaborative network. From the budgets presented by the actors, it was possible to notice that, although the NGO already works with social projects and demonstrated an interest in the partnership, its "cultural labor" cost was quite high, when compared to the budget presented by company 1 , which is highly qualified for the manufacturing of furniture (table 1 ).

Table 1 Preview of production costs

\begin{tabular}{|l|l|l|}
\hline Furniture & $\begin{array}{l}\text { Partner 1: Micro-enterprise } \\
3\end{array}$ & Partner 2: NGO \\
\hline $\begin{array}{l}\text { Re-Tales } \\
\text { Cabinet }\end{array}$ & R $\$ 700.00(\mathrm{U} \$ 212)$ & 2 weeks \\
\hline Bookshelf & $\mathrm{R} \$ 350.00(\mathrm{US} \$ 106)$ & 1 week \\
\hline Table & $\mathrm{R} \$ 200.00(\mathrm{US} \$ 60)$ & 3 days \\
\hline Stool & $\mathrm{R} \$ 90.00(\mathrm{U} \$ 27)$ & 1 day \\
\hline Total & $\mathrm{R} \$ 1340.00(\mathrm{U} \$ 405)$ & $\begin{array}{l}\mathrm{R} \$ 3500.00(\mathrm{U} \$ \\
1060)\end{array}$ \\
\hline
\end{tabular}

\section{Conclusion and Recommendations}

Throughout the whole process of the construction of the collaborative network and of contacting several actors, it was possible to observe how difficult it is to change a paradigm. It is difficult indeed, but not impossible. Regardless of the responses of the actors - whether positive or negative - throughout the process, this experience served as a study for the formation of the netw ork, where it was possible to observe, a mong other aspects, the vision or limitation of vision of potential actors, considering the social and sustainable approach of this proposal. Another important characteristic is the role of the designer, who must pay attention to opportunities for projects, connections, and collaboration, and can act as a facilitator of collaborative processes, working toward a more humane society.

About the development of products from the reuse of waste, in contexts of manual, nonautomated production, the great challenge on the part of the design is to make its execution feasible. This could also affect the configuration of the formal results, shape, and combination of parts, somehow limiting very innovative solutions. At the same time, it can be said that this difficulty stimulates the creative process in search of efficient solutions, in which it is possible to 
develop projects that are different from those that already exist. Additionally, even if the raw material used comes from MDF scraps, their characteristics are not different from those of other materials: in fact, it brings higher significance and importance to the furniture created. It is also worth noting that the budgets were presented to the Daycare partner organization. How ever, due to the bureaucratic procedures for the release of resources by the City Hall, the products were not yet purchased, and the deadlines were extended, which means a new budget will have to be drafted to update production costs. It is important to emphasize that, even in socially and environmentally positive initiatives, the actors that make up the more significant market also need to consider the economic viability. However, the experience reported in this work demonstrates that it is possible that inter-organizational collaborative networks can count on the companies, increasing their social and environmental responsibility and contributing to the paradigm change in both business management and social behavior, towards an integrated and more humanized worldview. However, only from concrete and continuous partnerships is it possible to advance in initiatives of this nature, in the process of social learning that demands time, will and determination. In this process, it is essential that all the actors commit themselves to the fulfillment of their role, responsibly and integrally, beginning with small pilot experiences aimed at achieving long-term sustainability goals.

\section{References}

- Abrão, Júlia S. (2017). Uso do Design para auxiliar no mapeamento e evolução do Setor Moveleiro de Uberlândia/MG. Relatório Final de Pesquisa de Iniciação Científica em Design. PIVIC. FAPEMIG2016-0359. Orientador: profa. Dra. Viviane G. A. Nunes. Faculdade de Arquitetura, Urbanismo e Design (FAUeD). Universidade Federal de Uberlândia (UFU). Uberlândia, MG.

- Abrão, Júlia S. (2017a) Design, Estratégia e Colaboração: Criação de um sistema como alternativa para o reaproveitamento de resíduos no setor moveleiro sob medida. Trabalho de Conclusão de Curso. Orientador: profa. Dra. Viviane G. A. Nunes. Faculdade de Arquitetura, Urbanismo e Design (FAUeD). Universidade Federal de Uberlândia (UFU). Uberlândia, MG.

- Bruce, M.; Cooper, R.; Vazquez, D. (1999). Effective design management for small businesses. Design Studies 20, 297-315. Crossref

- Bacigalupi, B. (2015) Unit F.1 "Resource efficiency \& economic analysis "European Commission, DG Environment. Working Groups. Environmental Accounts \& Environmental Expenditure Statistics. Luxembourg, 10 March 2015.

- Castro, Maria Luiza A. C.; Nunes, Viviane G. A. Apresentação: Projeto e Sustentabilidade. (2008) In: Castro, Maria L. A.C.; Nunes, Viviane G. A.. Os Desafios Projetuais na Construção da Sustentabilidade. Uberlândia: JT Soluções Gráficas Ltda/UFU, p. 8-16.

- Cavalcante, Ana L. B. L; Preto, S. C. ; Pereira, F. A. F.; Figueiredo, L. F. G. (2012). Design para a Sustentabilidade - um conceito interdisciplinar em construção. Projética Revista Científica de Design, Londrina, v. 3, n. 1, p.252-263, July. Crossref

- Chelala, C. M.S. A Questão Urbana a partir do Enfoque da Evolução Social. In: Castro, Maria L. A.C.; Nunes, Viviane G. A. (2008) Os Desafios Projetuais na Construção da Sustentabilidade. Uberlândia: JT Soluções Gráficas Ltda/ UFU, Cap. 2. p. 17-25.

- Clark, G.; Kosoris, J., Hong, L.N.; Crul, M. (2009). Design for Sustainability: Current Trends in Sustainable Product Design and Development. Sustainability, 1, 409-424; doi:10.3390/su1030409. ISSN 2071-1050. Retrieved in 03 May 2018, from www.mdpi.com/journal/sustainability Crossref

- European Environment Agency. (2017). Circular by design Products in the circular economy. Luxembourg: Publications Office of the European Union. ISBN 978-92-9213-8578 ISSN 1977-8449 doi:10.2800/860754

- Word Economic Forum. (2014). Towards the circular economy: accelerating the scale-up across global supply chains. Presented at World Economic Forum, Geneva, Switzerland. 
Design, Strategy, and Collaboration: A System an Alternative for Reusing Waste from the Bespoke Furniture Sector

Viviane G. A. Nunes, Júlia S. Abrão

- G1 Triângulo Mineiro. (2017). Uberlândia se mantém como 2a maior cidade de MG, segundo IBGE; confira levantamento na região. Retrieved in 10 Oct, 2017 from https://q1.globo.com/minas-gerais/trianqulo-mineiro/noticia/uberlandia-se-mantem-como2-maior-cidade-de-mg-segundo-ibge-confira-levantamento-na-regiao.ghtml

- Kazazian, Thierry. (2005). Design e desenvolvimento sustentável: Haverá a idade das coisas leves. São Paulo: SENAC. $194 \mathrm{p}$.

- Loss, Leandro. (2007). Um arcabouço para o aprendizado de redes colaborativas de organizações: Uma abordagem baseada em aprendizagem organizacional e gestão do conhecimento.. 245 f. Tese (Doutorado) - Curso de Engenharia Elétrica, Universidade Federal de Santa Catarina, Florianópolis.

- Manzini, E., Collina, L. \& Evans, S., (2004.) Solution oriented partnerships: how to design industrialised sustainable solutions. Cranfield University.

- Manzini, E. (2008). Design para a inovação social e sustentabilidade: Comunidades criativas, organizações colaborativas e novas redes projetuais. Rio de Janeiro: E-papers. 103 p. Trad.: Carla Cipolla.

- Nunes, Viviane G. A. (2013). Design Pilot Project as a Boundary Object: a strategy to foster sustainable design policies for Brazilian MSEs. Milan, Italy: Ph.D. Thesis in Design. INDACO Department, Polytechnic of Milan. 2013, 556p.

- Nunes, Viviane G. A. (2008). Design sustentável: [im] possível?. In Castro, M.L.; Nunes, Viviane G.A. (orgs) Os desafios projetuais na construção da sustentabilidade: Desafios projetuais: ecologia e sustentabilidade. Uberlândia: JT Soluções Gráficas Ltda/UFU. p. 6875.

- Oliveira, P., Alvarenga, A., Paes, F., Feitosa, F., \& Silva, J. (2012). Cadeia produtiva da movelaria: o polo moveleiro do Triangulo Mineiro. Viçosa/MG: EPAMIG, 44p.

- Resende, H. G. T. R. (2015). Design como contribuição para as Práticas Sustentáveis das micro e pequenas empresas moveleiras do Triângulo Mineiro. Orientadora: profa. dra. Viviane G. A. Nunes. Uso do Design como ferramenta estratégica na elaboração de diretrizes de fomento às práticas de Responsabilidade Socioambiental nas Micro e Pequenas Empresas do Setor Moveleiro da região do Triângulo Mineiro. Relatório Final.

- Rossi Filho, A., Meroni, A., Monti, C. \& Galisai, R. (2009). São Paulo Design Visions: Strategic design as an agent of dialog and transformation. Strategic Design Research Journal, Jul-Oct, 2(2), pp. 56-63. Crossref

- Scaletsky, C. C.; Costa, F. C., X.; Bittencourt, P. (2016). Reflexões sobre Design Estratégico. In: Scaletsky, Celso C. Design Estratégico em ação. São Leopoldo: Unisinos, Cap. 1. p. 14-17.

- Santos, A.; Vezzoli, C.; Cortesi, S. (2008). The Design Role On Corporate Social Responsibility. LeNS. Version 03/11/08., 60p.

- SENAI, FIEMG, SEBRAE, \& SINDMOB. (2006). Diagnóstico empresarial das indústrias moveleiras de Uberlândia e Região. Uberlândia: Sistema FIEMG. Pool Comunicação. 88p.

- Tachizawa, Takeshy. (2002). Gestão Ambiental e Responsabilidade Social Corporativa: Estratégias de Negócios Focadas na Realidade Brasileira. São Paulo: Atlas S/A. $381 \mathrm{p}$.

- Thiollent, Michel. (1985). Metodologia da Pesquisa-Ação. São Paulo: Cortez.

- Wildner, M.V. (2015). Reaproveitamento De Resíduos Da Indústria Moveleira Para Aplica ção Em Novos Produtos De Mobiliário. Trabalho de Conclusão de Curso. Design. Lajeado: Centro Universitário UNIVATES. 120p.

- Zurlo, F., Nunes, V.G.A. (2016). Designing Pilot Projects as Boundary Objects: a Brazilian case study in the promotion of sustainable design. Springer Cham: Heidelberg New York Dordrecht London. ISBN 978-3-319-23140-2. DOI 10.1007/978-3-309-23141-9. Crossref 